\title{
From AIDS to Free Trade Agreements: Knowledge Activism in Thailand's Movement for Access to Medicines
}

\author{
GAËLlE PASCALE KRIKORIAN \\ INSTITUT DE RECHERCHE INTERDISCIPLINAIRE SUR LES ENJEUX SOCIAUX
}

\begin{abstract}
This article examines the movement for access to medicines in Thailand, a country that is a privileged site of observation of the new world order of pharmaceuticals and has been at the forefront in many international negotiations on intellectual property. The movement relies on the appropriation of knowledge and expertise about intellectual property laws, which developed in the context of the fight against HIV/AIDS. Treatment activism in Thailand is particularly vigorous and studying it allows us to grasp both the national and transnational dimension of this type of collective action: a global movement that is structured around the notion of "access to medicines," and is in close but rather orthodox relation to medical knowledge. The relations that one can draw between AIDS activism and the movement for access-to-medicines allows one to trace the origins of the latter and helps us understand key features at the core of this movement. But the analysis also shows that, from the outset, the access to medicines movement in Thailand developed through a new form of activism. The notion of knowledge activism is developed in this paper to seize the particularities of the activism at play in Thailand as compared with other forms of collective action relying on the use of knowledge. Knowledge activism is defined not only by the activists' relation to knowledge - authoritative and institutionalized knowledge, or lay expertise-but also by the inclusion in the movement of "expert activists" such as doctors, lawyers, or academics, together with "grassroots activists." Knowledge activism also implies a permanent circulation of knowledge and information between the various categories of actors involved inside, outside and on the fringes of the movement, and results in a hybrid form of collective action that develops beyond the movement and is constantly reconfigured, according to opportunities or pressures.
\end{abstract}

\section{Keywords}

social movements; knowledge; intellectual property law; biomedicine; HIV/AIDS; Free Trade Agreement; Thailand

Gaëlle Pascale Krikorian, Email: gaelle.krikorian@gmail.com

Copyright (C) 2017 (Gaëlle Pascale Krikorian). Licensed under the Creative Commons Attribution Non-commercial No

Derivatives (by-nc-nd). Available at estsjournal.org. 


\section{Introduction}

Kamon Upkaew is a member of the Thai Network of People with HIV / AIDS (TNP+) in Thailand. A few years before we met, he did not know much about patents or their relation to medicines. In January 2006, however, as I was interviewing him about the mobilization of TNP+ against the Free Trade Agreement in negotiation with the USA, his statements clearly indicated that he had delved into the issue. He explained to me how his group was confronting the patent office in Thailand, criticizing the way it implemented "patentability criteria." Referring to an HIV medicines called Combivir ${ }^{\circledR}$, he pointed out that if they could not "get the review committee [of the patent office] to not issue the patent," they would "have to ask the ministry of public health to issue a CL [compulsory license]." ${ }_{2}$ He told me how TNP+, along with other NGOs, was educating people in the country about how and why "IP" (Intellectual Property) "would affect people with HIV." He explained how they had managed to gather thousands of people from the HIV networks to demonstrate against the FTA: as patients facing side effects with their current medicines realized that they could not get access to new treatments because of the existence of patents. Although he probably did not consider himself to be an expert, he struck me as being one. Within a few years in Thailand, people living with HIV, such as Kamon Upkaew, had become able to comment and criticize legal provisions on patents introduced in the FTA negotiations by the US delegation, even if they did not previously read or speak English.

Since the mid-1990s, scholars have described an emerging form of social mobilization of AIDS patients in Western countries who put biomedical knowledge at the heart of their action. They have produced a lay-expertise in biomedical research (Epstein 1995) and interfered and imposed themselves as credible participants in the process of knowledge production of biomedical research (Dalgalarrondo 2004). In doing so, they have opened up "the specialized world of controlled clinical trials" (Dodier 2003), and questioned the monopoly of the medical power over this knowledge and over medical decisions; finally, they have brought forth their own definition of how medicine should be practiced (Barbot 2002). Some researchers evoke "treatment activism" (Epstein 1995) or "therapeutic activism" (Barbot 2002) to describe the sort of activism that is targeting the disease itself (Rabeharisoa 2006), rejecting the figure of the patient as a victim of the disease and concentrating on the action of the deadly virus. Others refer to therapeutic citizenship to point out the influence of biomedical knowledge in the governing of people with HIV, the willingness of these patients to participate in the research, and the politicization related to it (Nguyen 2005). These notions, though different, highlight a similar mobilization of patients toward the production and circulation of medical knowledge. This phenomenon was described in various countries including the United States (Epstein 1995, 1996), France (Dodier and Barbot 2000), South Africa (Robins 2004), Brazil (Biehl 2004), West Africa (Nguyen 2010), and Thailand (Krikorian 2014). In the Global South, the necessity for groups of patients to interfere in the medical territory rests on the fact that medical decisions are complicated by a series of factors, some of which are not at all or less present than in the North:

' Compulsory licensing is a legal provision from the Thai patent law and the World Trade Organization (WTO) that allows governments to suspend patent protection in order to allow local production or the importation of generic medicines. 
limited therapeutic options with regard to the full spectrum of existing possibilities at an international level, the general complexity of the drug combinations, the heavy side effects of some of the molecules and the limited experience with these treatments of medical practitioners. Each organization or community may have a specific vision of the figure of the patient and its relation to the medical institution, or a different vision of the role of the public authority, but they share the belief that patients may and should engage with medical science. Activists' slogans such as "Knowledge is a weapon" (Act Up New York, USA), "Information = Pouvoir" (Act Up Paris, France), "Treatment preparedness" (International Treatment Preparedness Coalition, an international coalition of activists from various countries: Kenya, Thailand, Morocco, the United States of America, India, etc.), "informação é arma" (ABIA, Brésil) reflect AIDS activists' dispositions, in different countries, in respect of knowledge and their efforts to reach, penetrate, and master the inner sanctum of biomedical experts in order to take part in medical and political decisions that affect them.

Since the end of the 1990s, the central place of medicines in HIV care has emerged, locally and internationally, via demands for access to antiretroviral medicines in developing countries where it was sorely lacking. To support their demands, AIDS activists around the world began to turn to generic versions of these treatments and the effect of competition on prices. And so while still deeply immersed in treatment activism, many groups entered a new political sphere and a new field of expertise: intellectual property laws that establish monopolies on medicines through patents. At first, they focused on the World Trade Organization that sets international standards. But, rapidly, they became key opponents of Free Trade Agreements that had spearheaded the rise in intellectual property protection standards (Krikorian and Szymkowiak 2007).

This article examines the emergence and actions of the movement for access to medicines that relies on the appropriation of knowledge and expertise about intellectual property laws which developed in the context of the fight against HIV / AIDS in the Global South. It first aims to present how a global movement structured itself around the notion of "access to medicines" in close but rather orthodox relation to medical knowledge. It then looks into the way this movement organized itself and engaged with intellectual property issues in Thailand, drawing on research conducted on the issue of access to medicines and intellectual property protections in the context of the negotiation of free trade agreements. Thailand was engaged in a negotiation with the United States of America when the fieldwork was conducted. As a middle-income country with a local pharmaceutical industry (both publicly and privately owned), it has been at the forefront of many international negotiations on intellectual property since the end of the 1990s, which makes it a privileged site of observation for the new world order of pharmaceuticals (Petryna et al. 2006). The movement for access to medicines, particularly vigorous in Thailand and with solid ties to individuals and groups involved in access to medicines movements abroad, turned out to be an important player in the process of opposing the trade agreement with the

${ }^{3}$ The terms "North" and "Global South," "developing countries" and "rich countries" adopted in this article correspond to indigenous terms used by the actors. It also reflects the geopolitical distinction imposed by the unequal pressure of the HIV/AIDS epidemic across continents and the problematization of access to ARV worldwide. 
United States.

The fieldwork underpinning the analysis presented in this article consisted of observations during meetings, conferences, rallies, press conferences, and other events that took place between 2006 and 2009. Reviews and analyses of media and gray literature (statements, reports, government documents, leaked documents, working papers, drafts legislations, etc.) have supplemented 51 semi-structured interviews conducted in Thailand with activists and members of NGOs, academics, journalists, lawmakers, representatives of national institutions, donor agencies and international organizations, pharmaceutical companies.

The main idea of this article is that the emergence of the form of activism operating in this context is more than an extension of the appropriation of knowledge in a new field by activists already engaged in medical science. Thus, my task is both to highlight the existing relation between treatment activism and this new form of activism, and to show how the latter developed specific features. To do so, I look at this new form of activism with the theoretical tools developed by scholars that worked on treatment activism, but more broadly on Health Social Movements (HSMs) (Brown et al. (2004)), Evidence Base Activism (EBA) (Rabeharisoa et al. 2014) and "democratizing science movements" (McCormick 2007). I coin the notion of knowledge activism in order to reveal particularities of the activism at play in Thailand as compared with other forms of collective action relying on the use of knowledge.

Knowledge activism derives from AIDS therapeutic activism and is based on the acquisition and use by lay persons of specific authoritative and institutionalized knowledge (Bourdieu 1983). The understanding of intellectual property law is learned through a peer-to-peer apparatus, outside of the education system. Becoming "lay experts" (Epstein 1995), knowledge activists also grow into "credible interlocutors of specialists" (Rabeharisoa op. cit.). Their activism is based on promoting challenging interpretations of the law and of the legality of various policies against that of traditional experts. In doing so, rather than defying the authority of science or of the law, they question the scientists' and the lawyers' monopoly over knowledge and decision making. This allows them to challenge the current economy of pharmaceuticals while building their own legitimacy.

But knowledge activism is not only defined by the activists' relation to knowledge (authoritative and institutionalized knowledge, or lay expertise); it also implies a certain relation and circulation of knowledge and information between different categories of actors. By this I mean that within the movement there is no strict dichotomy between lay persons and specialists of IP. Categories are transformed-IP lawyers and experts act as activists, while HIV patients are trained to explain the question of IP law-and knowledge circulates between them. A continuum of knowledge and information also extends outside the movement, from grassroots activists to civil servants and policy makers. Thus, knowledge activism is the result of a hybrid form of collective action that develops beyond the movement.

This conceptualization of knowledge activism is based on two principles. First, the use and production of knowledge by social movements is a trend in many domains and is not specific to health or social issues directly affected by science and technology, and knowledge activism reflects this trend among social movements where activists have a dynamic relation to 
knowledge and information-generally some type of sciences - that are appropriated, used or challenged. Second, knowledge activism entails a certain kind of relation and circulation of knowledge and information among a range of different types of actors-_"grassroots" activist, "expert" activists, such as doctors, lawyers, pharmacists, academics, journalists, but also civil servants and representatives of public institutions. I argue that knowledge activism is based on: (1) the lay person's acquiring and using specific authoritative and institutionalized knowledge; (2) the lay person making the interpretation and use of this knowledge the object of contention; (3) the lay person developing alternative interpretations and uses of his or her knowledge; and (4) the circulation knowledge and information among different actors serving the movement-including lay persons considered as "grassroots" activists and "expert" activists such as doctors, lawyers, or academics, but also allies outside the movement.

\section{The Access to Medicines Movement}

\section{A Global Movement Articulating the Local and the Global}

During the international AIDS conference held in Vancouver in July 1996, scientists for the first time publicly released evidence of the efficacy of the highly active antiretroviral triple therapy (HAART) against the HIV virus. With this therapeutic revolution, the issue of inequality of access to therapy in the Global South arose within the community of the patients and associations fighting AIDS. Demands for treatments emerged in the Global South, first in middle-income countries, and in poorer countries soon after. In Vancouver, Eric Sawyer, a representative of the activist group of people with AIDS ACT UP New York, gave a speech at the opening of the conference. He insisted on the gross inequality in having access to treatments, the need "to get treatments into developing countries" where the majority of the people with HIV / AIDS were living, and finished his speech exclaiming: "Demand access to All" (ACT UP 1996). A triple therapy cost around $\$ 10,000$ US per patient per year at the time, which kept it out of reach for most of the HIV-infected people, 95\% of whom lived in the Global South.

A global movement anchored in the demand for universal access to antiretroviral drugs for all patients, and more broadly equal access to medicines for all in general, emerged in the following years. It aggregated grassroots groups and networks of people with HIV / AIDS from many countries (Colombia, Costa Rica, Brazil, Argentina, Thailand, South Africa, France, the United States, etc.) together with some medical doctors and researchers, NGOs caring for patients in developing countries (Médecins Sans Frontières) or advocating on a global scale for access to healthcare (Health Action International), groups lobbying against inequalities in the Global South (Third World Network), NGOs fighting inequalities and poverty (Oxfam), and groups working on intellectual property (CPTech). The emerging access movement thus stemmed from the alliance of entities that were part of what is referred to as a "Global AIDS activist movement" (Parker 2011: 27) and entities from different fields of social justice, global justice, and humanitarian action. The term "movement" conceals a diversity of organizations and dynamics, "groups, organizations, bundles of social ties, and social sites," as Tilly stated (2005: 61). Indeed, it is a loose association of local organizations and organizations with a global scope (Kapstein and 
Busby 2013) that forms this global mobilization. NGOs active internationally display a diversity of cultures of intervention and of repertoires of action. Local groups and networks of people with HIV / AIDS each have their characteristics as influenced by their political and cultural national contexts, but they have in common a reliance on collective action in public space, confronting policy makers, and building peer-to-peer solidarity. All these groups want to exert pressure in order to challenge the policies of the national institutions and international bodies that shape the response to the AIDS epidemic in the Global South (the World Bank, the WHO, UNAIDS, etc.). They endeavor to reduce the price of drugs and render access to medicines possible anywhere in the world. To reach this objective, each component of the movement acts individually or collectively, depending on the circumstances. If tensions are not absent, ${ }^{*}$ the strength of the movement as a whole lies in its capacity to incorporate and articulate complementary modes of action (institutionalized lobbying in international institutions in Geneva, or direct confrontational public action such as ACT UP's "zaps," for instance). Both the efficiency and the global nature of this "composite network" (Tilly, op. cit.) lies in its capacity to be present globally (thanks to global days of action, for instance, and other types of collective actions) and cover the debates taking place within international institutions (WHO, WTO, UN, etc.), while also being present "on the ground," as they are either people living with the disease or their doctors and supporters.

\section{A New Notion of Access}

Scholars have shown how activists mobilized to accelerate the access to medicines, in the US or in France, during the early course of the AIDS epidemic (Epstein 1995, 1996; Dalgalarrondo and Urfalino 2000). At that time, therapeutic options were few and of limited efficiency. Patients acquired medical and scientific knowledge in order to be able to discuss with researchers, physicians, governmental agencies and to put forward their demand for medicines. They committed to clinical trials and research. When the issue of access to medicines emerged as an issue of equality between the North and the South, the terms of the debate changed.

At the end of the 1980s and during the 1990s, activists clashed with the pharmaceutical companies arguing for the acceleration of research and conduct of clinical trials; they targeted the regulation agencies so that new products could be registered more quickly and so that patients could have access to these products more rapidly via compassionate use (Epstein 1996; Barbot 1998). Issues about draws among patients arose in the North because medicines were not available in sufficient quantities (Dalgalarrondo and Urfalino 2000). "Putting the medicines into bodies" became a slogan (Epstein, 1996). The same catchphrase was used later about access to antiretrovirals in developing countries. However, the barriers preventing those patients from having access to the medicines were of a different nature.

In the 1990s, patients were "chasing new molecules" (Dalgalarrondo and Urfalino op.cit.: 119); in the 2000s, efficient drug combinations existed. In most countries, they were used by a small minority of patients (an elite that had access to them generally outside the public services),

4 They may be due to differences in activism cultures, strategic choice, language misunderstanding. 
but they remained unaffordable to most patients and to most healthcare systems. For various reasons, pharmaceutical companies were not interested in conforming prices with the level of economic resources available in the various countries. However, since they owned the patents on these medicines, they could prevent other companies from producing or selling generic versions of the medicines. Thus, groups of patients and NGOs turned their attention to the legal framework surrounding the regulation of the pharmaceutical market, specifically the intellectual property laws that define patent protection and monopolies on the market. The pharmaceutical industry and many governmental or international donors pointed to the lack of roads, clean water, and the inadequacy of the health systems in developing countries. However, advocates for the access to antiretrovirals targeted prices and monopolies.

Not all activists or groups within the access movement looked into intellectual property rules, but a significant part did, and they succeeded in bringing these issues to the core of the public debate over access to medicines. In the context of the Global South, it was thus reconfigured with regard to the issue of patents. The highly publicized lawsuit by 39 pharmaceutical multinationals in Pretoria against the South African government over an amendment of the law aiming at facilitating the access to medicines ${ }^{5}$ was emblematic of this phenomenon.

Intellectual property rules that prevented access to generic medicines--which could cost less than $10 \%$ of the price of the patented medicines, as local production in Brazil or India at the beginning of the 2000s demonstrated-emerged as a key dimension of what became a political problem. This is illustrated by the fact that the World Trade Organization (WTO), which sets international standards for intellectual property protection, became both a target of AIDS activists and a new political arena where access to medicines was discussed. A new notion of access to medicines was forged that was both contextualized in time and space and rooted in ideas of justice and equality that take into consideration ill people's human rights in their relation to commercial rights and rules: it emerged in the context of the global AIDS epidemic, in reaction to the patients' inequality of access to medicines across the world, and in tensions with the intellectual property rules governing the pharmaceutical market. This notion structures the mobilization as much as it is produced by it.

The global dimension of this mobilization derives both from the message of universal access that it conveys, and from the interconnection of networks of organizations and individuals that constitute it-typical of what started to be labeled "Global Health" (Fassin 2015). Despite local specificities of epidemiological data and health systems, the community of experiences (Broqua et al. 1996) of the disease, of its deadly threat, and of the capacity of the medicines to fight the virus, had induced across the globe an idea and a perception of what is acceptable or unacceptable in terms of access to medicines for the HIV carriers. This has formed the base for global claims targeting international institutions and donors, and it has also been used domestically by members of the movement, in their national context, where they redefined their

${ }^{5}$ The South African Medicines and Related Substances Control Act (MRSCA) was amended by the government in order to allow the purchase of cheaper medicines from abroad. For more details see for instance Fisher and Rigamonti (2005). 
understanding of access taking into account local realities (resources, laws, etc.). The global nature of the issue of access to medicines is thus constituted by the production of a notion of access that all members of the movement relate to and use, as well as a redefinition of this global issue in local contexts. As I will show below, the emergence of this new framing of the issue of "access" corresponds to the investment of a new form of knowledge and to a specific form of activism.

\section{Relation to Knowledge and Knowledge Institutions}

The sociological lens of Health Social Movements (HSMs) provides theoretical tools to analyze the movement for access to medicines and its relation to knowledge. Brown et al. (2004) subdivided HSMs into three categories: health access movements that seek equitable access to healthcare and want to improve the provision of healthcare; constituency-based health movements that denounce health inequality and inequity based on race, ethnicity, gender, class and/or sexuality differences; and embodied health movements (EHMs) that address the experience of a disease, disability or illness by challenging science on etiology, diagnosis, treatment, and prevention. The concerns and actions of the movement for access to medicines meet the goals of these three categories. The movement seeks equitable access to medicines for all, which often rests on the improvement of medical coverage among the population and the increase of resources to be able to purchase health products. It denounces inequality in access between the North and the South, between the rich and the poor, and for categories of people who are socially marginalized and who have poor access to health facilities, such as drug users, prisoners, etc. Finally, it is marked by the deep imprint of HIV activism and its "embodied nature" (ibid.), putting the biological body and the experience of people with the disease at the center of the movement.

EHMs typically include challenges to existing medical/scientific knowledge and practices, though they often also imply collaboration with scientists and health professionals in pursuing treatment, prevention, research, and additional funding. Not all groups from the accessto-medicines movement possess these features, but HIV-positive people's networks and HIV / AIDS activist groups do, and, overall, these patterns are all represented in the movement. The access-to-medicines movement combines the two tendencies of the continuum that Brown and al. use to characterize HSMs. Some are "activist-oriented" and "engage in direct action, challenge current scientific and medical paradigms, and pursue democratic participation in scientific or policy-knowledge production by working largely outside the system." Others are more oriented towards "advocacy" and "work within the existing system and biomedical model, use tactics other than direct, disruptive action (e.g. education), and tend not to push for lay knowledge to be inserted into expert knowledge systems" (ibid.). Groups like Health Gap, Act Up, Treatment Action Campaign, for instance, are specialized in direct action, public demonstrations, and use disruptive tactics in order to be listened to by the biomedical system.

Overall, the movement's relation to scientific knowledge has been deeply influenced by the therapeutic activism inherited from the first decade of the struggles against HIV/AIDS that 
flourished in groups of HIV positive people and instilled in the AIDS community. Through the specific action of some of its members, and thanks to its diversity, the access movement is able to "blur the boundaries between lay and expert forms of knowledge, and between activists and the state" (ibid.). However, although "lay knowledge" of people living with HIV is being referred to and promoted by many groups within the access movement, in comparison to other HSMs (or social movements working on the environment), pushing for lay expertise and knowledge is not as important or central in the action of the access movement. AIDS activists changed medical science from within. That is, they challenged authoritative experts and made their voice heard (Epstein 2008). Similarly, the access movement questions the way science is done, but in many ways it does not challenge the authority or role of science or its place in society. The biomedical system and chemical drugs are considered to be the best option for patients, as are recent general trends such as the evolutions of molecular biology or the prominence of evidence-based medicine and the intensification of clinical research practices. Within the access movement the facts that the HIV virus causes AIDS, or that triple therapies of antiretrovirals are efficient to fight HIV are not questioned--the strong opposition of members of the movement to revisionists, in the US or in South Africa, for example, is one illustration of this stance toward medicines and science. The requirements imposed by science may be readjusted punctually: in many cases, patients' organizations criticized the rules of inclusion or the use of placebo, and NGOs such as MSF became involved in the organizing of trials with research agencies, for example. But the methodology of clinical studies in itself is considered to be the best way to establish the medical proof, and the conclusions reached by clinical research are generally accepted as ultimate and unquestionable truths.

In other words, the access-to-medicines movement uses science rather conventionally. Beyond the issue of medical research and development, all kinds of scientific data were potentially mobilized in order to have an impact on policy-making and governance related to medicines. It summons up medical science in order to prove the efficacy of antiretrovirals in developing countries, or the compliance of patients in these countries to counter the political arguments according to which these drugs should not be prescribed there. Activists also invoke economics in the context of health management to demonstrate that treating patients is less costly for countries than hospitalization, absenteeism at work, and deaths. MSF, for instance, explained in 2000:

The availability of cheap drugs had enabled the Brazilian Government to provide antiretrovirals to more than 80,000 citizens by the end of 1999 , which led to a more than 50\% drop in AIDS-related morality between 1996 and 1999. (...) In 1997 there were 580,000 people living with HIV / AIDS in Brazil. (...) this allowed the government to save more than US\$472 million on hospitalisations and treatment for opportunistic infections between 1997 and 1999. This demonstrates that when ARVs are available at affordable levels, in addition to the high social cost of not providing them there are real financial costs. It can become more expensive for government not to offer ARVs than to provide them, because of the high cost associated with caring for people with AIDS. (Pérez-Casas, 2000) 


\section{From Medical Science to Intellectual Property Law: The Deployment of Knowledge Activism \\ Delving into the Issue of Patents}

At the end of the 1990s, the emerging access-to-medicines movement (henceforth AMM) confronted a new field of expertise that was very different from medical science and at first unknown to most of its members: intellectual property law. Activists began turning their attention to patent issues. As an AIDS activist recalls:

Originally, MSF was more scientific, about sharing information about treatment. (...) As [its] project was expanding, we started to be more aware of drug issues, and that was then that the patent stuff popped up... information about drugs barriers. (Interview with Kamon Upkaew from the Thailand Network of People Living with HIV / AIDS (TNP+), January 26, 2006)

The social mobilization against HIV in Thailand originally focused on fighting discrimination against people living with the virus. By the mid-1990s, it embraced access to medicines. This issue became the major focus for the Thai NGO (Non-Governmental Organization) Coalition on AIDS (TNCA), a coalition that gathers all the groups mobilized against AIDS in the country. A new entity, the Thai Network of People Living With HIV and Aids (TNP+), launched in 1998 and formed the cornerstone of the movement for access to medicines, together with the AIDS Access Foundation, a Thai NGO established in 1991, and Médecins Sans Frontières (MSF) Belgium, which has had operational activities in Thailand. At the end of the 1990s, Thailand was equipped with a local AMM that combined local NGOs with strong ties in other segments of Thai civil society, a network of people with HIV / AIDS distributed across the country," and the support of international NGOs with resources and technical expertise.

This movement also rests on the support of activists in Thai academia. One of the linchpins in the AMM is the Drug Study Group, a group of academics from various universities created in 1975, and active since then, tackling the issues of access to essential drugs, rational drug use, and consumer protection. In the mid-1980s, these academics started to look into the issue of generic medicines and patent protection. The United States of America pressured other countries into implementing national legislation that would reinforce patent protection in Thai law. The Drug Study Group conducted an investigation into the impact on Thailand's healthcare system of increased patent protection on medicines; it showed that higher levels of protection would significantly increase the purchase of imported drugs and hinder the development of the national drug industry. The interest of the members of the Drug Study Group for intellectual

- At the time TNP+ had seven regional offices and 48 full-time staff (Interview with Kamon Upkaew from the Thailand Network of People Living with HIV / AIDS (TNP+), January 26, 2006).

- Indeed, an increase in intellectual property protections would result in longer monopoly periods covering medicines, preventing the production of generic versions by the local industry. 
property derived from the work they conducted on the rational use of drug and access to essential medicines--for instance, to limit medication overuse. Together with other groups, the Drug Study Group ran a campaign to oppose increases in the protection of intellectual property requested by the industry and the US government. Nonetheless, the Thai government gave in to US pressure and amended the Patent Act in 1992, which resulted in tighter patent protection. Despite this failure, the ties between academics and NGOs have remained strong; academics contributed to the education of activists about what patents are and what their impact is.

When the AIDS conference in Vancouver took place in 1996, the price of therapy in developing countries was almost equivalent to that in Western countries, around $\$ 10,000$ US per patient per year. There is no universal health coverage in Thailand and patients have to pay for their treatment. Tri- therapy or bi- therapy-which was then the therapeutic standard-were out of reach for the vast majority of the patients in Thailand. This situation prompted the Governmental Pharmaceutical Organization (GPO) to manufacture several of the drugs commonly included in these combinations, among which is the antiretroviral ddI. The pharmaceutical company Bristol-Myers-Squibb (BMS) got involved: because the company had control of the patent of an improved version of this antiretroviral (containing anti-acids to facilitate its absorption), it claimed exclusive rights on ddI. GPO was willing to market a generic version using their own original process, which would have lowered the cost by approximately $40 \%$ (Kuanpoth 2010). Because of BMS's claim, however, the manufacturer abandoned production. As a consequence, AIDS activists and public health experts suggested that the government should have taken advantage of the flexibility of international laws on intellectual property, called compulsory license-a legal provision that makes it possible for governments to suspend patent protection in order to allow local production or import generic medicines. In 1997, GPO submitted a request for a compulsory license to the patent office. In 1998, NGOs together with the Drug Study Group organized several meetings and launched a national campaign. On December 22 and 23, 1999, hundreds of people with HIV / AIDS and NGO activists set up tents for a sit-in in front of the Ministry of Public Health in a two-day-long demonstration. They demanded that compulsory licensing be resorted to in order to authorize local production of ddI tablets (Limpananont 2005).

In reaction to the GPO's attempt to produce the drug, the Pharmaceutical Research and Manufacturers of America (PhRMA) urged the government of the United States to pressure

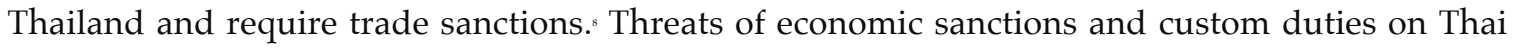
exports to the US, particularly wood and jewelry, led the Thai government to abandon its intention to use compulsory licensing. However, AIDS activists and GPO workers joined forces. Jon Ungpakorn, founder of the AIDS Access foundation, remembers:

" In February 1999, it submitted its annual report for the "301 list," requiring the addition of Thailand to the Priority Watch List. Every year, under the section "special," 301 of the US law adopted in 1988, the United State Trade Representative (USTR) establishes a list of the countries that apply "inadequate protection" to intellectual property and has a mandate to issue sanctions. Countries are classified in different categories according to the seriousness of the situation: Priority Foreign Country. Priority Watch List, Watch List, Section 306 Monitoring. Thailand remains on the Watch List, despite a recent amendment to Thai law that aims to consolidate intellectual property. 
With ddI, I think major factors that helped us were Dr. Krisana at GPO and the GPO union who supported us. They marched along in all our demonstrations. We didn't even know them at first. We were demonstrating in front of the MOH and the union came. They came with us to the US Embassy also. (Interview with Ungpakorn, senator of Thailand from 2000 to 2006, September 3, 2007)

As the Thai government rejected the option of compulsory licensing and asked GPO to limit its production to ddI powder (which is not protected by the BMS patent), NGOs and networks of people with HIV / AIDS delved deeper into the technicalities of the issue. They reoriented their efforts toward a court case against BMS and the Department of Intellectual property of the Ministry of Commerce. The AIDS Access Foundation and groups of people living with HIV lodged an appeal in May 2001 to oppose the patent on the formulation of ddI. They accused BMS of having intentionally deleted references to dosage in the patent description after it had filed the patent at the Department of Intellectual Property, allowing it to safeguard its right to the drug regardless of dosage. On October 1, 2002, the Thai Central Intellectual property and International Trade Court (CIPITC) ruled that the deletion of the dosage indication extended the range of the patent beyond what it originally covered and ordered BMS and the Department of Intellectual Property to correct the patent and restore the stipulation of dosage. In 2003, the Foundation for Consumers, a Thai consumers' organization with strong ties with the Drug Study Group, and people living with HIV requested the revocation of the BMS patent on ddI. They invoked several sophisticated arguments questioning the patentability of the product.' In December 2003, BMS put an end to the trial by relinquishing its patent (Limpananont 2005). Going to court was a way for activists to serve a concrete goal--access for patients to a molecule. It was also a fast learning episode for the community that initiated the legal action and thus gained knowledge about patents. Similar experiences took place in other countries, for instance, in South Africa where trials also became a key element in the strategy of treatment activists (Kapczynski and Berger 2009; Heywood 2009). To engage in these legal proceedings, the AIDS Access Foundation and the people living with HIV relied on the support of Thai academics and Thai lawyers, as well as a few experts in foreign organizations, MSF among others. Their local action was also tied to a larger mobilization and nexus of transnational collaborations, typical of the access-to-medicines movement: treatment activists with international scope in other countries, such as South Africa, India, the US, and France, were following closely the developments of the cases in Thailand, supporting the action of their Thai counterparts, and voicing their support each time they were asked to do so. As a result of this learning process, Thai people with HIV unable to speak or read English have now a precise opinion about patents filled (in English) by multinationals. They know the status of the examination process of these patents; they may know of legal and scientific arguments according to which the patent office in Thailand should refuse to grant these

- First, when BMS filed its first patent request in 1991, the law did not permit patenting of pharmaceutical products. Second, since, at the time of the patent request, ddI was already on the market and information about it public, it could not qualify as an invention. Finally, the product did not match the criteria for inventiveness. 
patents; and they even know the legal mechanisms existing in international agreements to allow their government to lift these patents in case they were to be granted (Interview with Kamon Upkaew from TNP+, January 26, 2006). They are in touch with people within the Ministry of Health, the Ministry of Commerce, and the patent office on this matter. Furthermore, they are able to mobilize their national network of people with HIV on this issue to demonstrate whether they believe public action is the only possible action to make themselves heard.

\section{Popular Education about Intellectual Property Rules}

A few years later, in January 2006, people with HIV and AIDS activists represented a large portion of the protestors demonstrating against the US free trade agreements during the 6th round of negotiation in Chiang Mai. 10,000 people took to the streets, and many reports mentioned that a third of them belonged to the HIV networks. They opposed the agreement for fear that provisions increasing intellectual property protection would impact access to medicines. Kamon Upkaew from TNP+ recalls that they heard originally about the FTA from academics in 2003. Before that, "TNP didn't have an updated policy to do FTA work." The case on ddI was the first collaboration with the academics. "[A] working group started to form around the kind of drugs that people with HIV would need, what they were able to make here in Thailand, and kind of started working together with the community, the academics, and the people producing the drugs." As a result, TNP+ began:

educating the network about the following issues: what is the FTA? What are the things related to IP that would affect people with HIV? And we started to do work in the country (...). (Interview with Kamon Upkaew from TNP+, January 26, 2006)

Nimit Tienudom, from the Access Foundation, explained to me how demonstrations they organized to oppose the patenting on Combivir ${ }^{\circledR}$ helped patients understand what was at stake with the FTA (Interview with Nimit Tienudom, director of the AIDS Access Foundation, February 1, 2006). People had to be able to see differences between "good or bad practices of the Thai government" regarding the patent system. With a good patent law, and they considered the Thai patent law was so, and if implemented properly by the institutions, Combivir ${ }^{\circledR}$ would not get a patent, because it did not deserve it. With the FTA, there would be new rules more favorable to the companies applying for patents, and Combivir ${ }^{\circledR}$ would be patented, and therefore inaccessible. AIDS activists worked to establish a clear connection between the daily life and needs of patients and the effect of the FTA on the Thai patent policy. Dr. Jiraporn Limpananont, a member of the Drug Study Group, is convinced that the sharing and transfer of knowledge and expertise accounted for this mass mobilization: thousands of people came to Chiang Mai because they were worried about what the impact of the agreement may have been for them, individually (Interview, January 17, 2006). In these mobilizations, experts from academia were an integral part of the collective action: they belonged to Chulalongkorn university, to GPO, to FTA Watch, etc. They acted as "expert activists," i.e. "individuals holding 
graduate degrees in a particular profession or field of research who use their academic skills and credentials to further social movement goals" (Frickel et al. 2014). In this way, academics and lawyers were at the core of the access to medicines movement. It is the collaboration between them and the rest of the AIDS and health activists in the movement that made the knowledge and language appropriation, and their use, possible, which, in turn, as we shall see, characterizes the form of activism in action.

Jon Ungpakorn mentioned the relationships of solidarity that allow knowledge exchanges: they often rest on preexisting connections and relationships first established in the fight against HIV / AIDS (interview September 3, 2007). Because the country was, at the beginning of the 2000s, considered exemplary by international agencies on account of its prevention policies, it was frequently visited by actors engaged in the HIV/AIDS fight. Training programs with foreign experts were organized. Thailand was selected three times within a couple of years as the site for regional and international conferences. Many "visitors from other countries" came to Thailand. Ungpakorn recalled meetings with activists from South Africa, where intellectual property became a serious issue in the fight against HIV/AIDS at the end of the 1990s. Thai activists quickly "became more exposed to the international scene." But the capacity of HIV groups to become knowledgeable and active in the field of intellectual property does not originate only in the existence of network of resources and collaborations. Individuals became involved because they thought there was a direct connection between the price of a medicine and the status of the patents that covered it. Jon Ungphakorn describes how the matter became prominent for the AIDS Foundation. The first concrete case was the fluconazole, an antifungal required to fight certain opportunistic infections, in 1998. The brand name product was sold at a prohibitive price. The "awareness" inside the group about the role and effect of patents came from visiting and supporting patients at home who needed the fluconazole that was kept out of their reach due to its price. Patients and NGOs knew of the existence of generics in other countries, but they also knew, because there was a patent in Thailand, that it was not possible to buy generics. First, activists organized weekly meetings at MSF on the matter; then, Thai experts started to collaborate closely to build up awareness of the impact of intellectual property. Ungphakorn and Tienudom adopted an approach to intellectual property law similar to what their therapeutic activism had been to medical science and medical authority. They learnt what a patent was, what the international norms stated, what the legal notions meant.

Patients are generally close to the medical environment (though proximity does not necessarily lead to acceptance, as is illustrated in the deaf community (see Blume 1999)), but it can facilitate access to knowledge. Therapeutic activism developed among poor people who were affected by the virus, despite the fact that they were sometimes distant from the medical environment--as it is the case of members of TTAG or TPN+ in Thailand. ${ }^{10}$ With the emergence of the issue of generics, the knowledge mobilized by the AMM went beyond the scope of medical

10 If some patients in rural area have a good "treatment literacy" (Wilson et al. 2009), many marginalized patients are kept at a distance from expensive medicines, just like they are from therapeutic knowledge (Biehl 2010). 
research and biomedicines: it started addressing intellectual property law. The access-tomedicines movement in Thailand thus developed a feature highlighted by scholars about Evidence Base Activism (EBA). In some cases, the knowledge involved stemmed from social sciences or education sciences (see, for instance Rabeharisoa et al. 2014; Moreira et al. 2014; Edwards et al. 2014). Stuart Blume $(1999 ; 2000)$ has also shown how the deaf community rejects the institutionalized biomedical knowledge but rests on sociolinguistics, psychological and sociological knowledge, to demonstrate that sign language is a language per se, empowering deaf people "in the struggle for an equal place in society"; by contrast, the effects of medico-surgical (cochlear) implantation in children, on many levels, remains uncertain. Similarly, the AMM in Thailand illustrates the deployment of such a form of activism that can turn to different fields of knowledge, even ones that are very distant from the activists' everyday life. Thus, its action is more about a relationship to knowledge in general than the appropriation of a certain kind of knowledge.

\section{A Rather Orthodox Relation to Knowledge}

At first, treatment activists focused on the recently established World Trade Organization (WTO) and its TRIPS agreement, which defined international standards of protection for intellectual property for all member states. Some of them were part of a broader NGO coalition in Thailand that targeted the WTO during the 1990s, or were in contact with those who did. Meetings about the "evaluation of TRIPS" took place in Bangkok. Activists saw "TRIPS as protecting patents" (Ungphakorn, interview September 3, 2007) and patents as preventing access. A demonstration was organized, and activists held a banner reading "TRIPS= Trade Related Inaccessibility to Pharmaceuticals." Ungphakorn recalled that many activists had "negative attitude towards TRIPS" and were very critical about patents themselves. However, activists did not reject intellectual property policies, nor the existing WTO standards. They did not challenge the fact that Thailand as a member of WTO had to implement its policies. In fact, their strategy focused on showing the impact of intellectual property protections on access to medicines, in particular of the increased patent protection-something often not taken into account by lawmakers, as government experts dealing with intellectual property rarely have healthcare background (or interest in the matter). Thus, activists attempted to penetrate the legal sub-culture of an elite (of lawyers, negotiators, policy makers, etc.) with the intention of voicing criticisms.

However, to a certain extent, activists' usage of knowledge also reinforces the authority of intellectual property rules. Interpretations of the law are at the core of what is challenged by activists, not the overall architecture of the rules or their existence." When they stepped into a battle about generics and started to raise the issue of the WTO rules on intellectual property at the end of the 1990s, treatment activists did not take a strong stance against the IP and patent system as such. Slogans like "patents kill" or "death under patent" were used by some of them,

"Nevertheless, some activists and groups within the access movement, inside and outside Thailand, across time, have developed a broader questioning of the IP system, and of the financing of medical research and development (Love 2011). But that is another story. 
but, overall, an unspoken consensus emerged amongst the movement to avoid a too radical speech. This strategy carries a form of ambivalence. Efforts mostly focused on interpretations of aspects of the WTO rules on IP, though not the rejection or amendment of these rules. For instance, they targeted the conditions or the provisions in international rules that make it possible to refuse to issue a patent, to suspend the exclusive rights it grants, or to revoke it. They spent much of their energy clarifying that the flexibilities of the system to lift a patent protection and produce generics (compulsory licensing) could be used by states. But they did not challenge the principle of granting a 20-year-long monopoly protection on medicines through a patent, nor did they protest against the fact that the rules set by the WTO on intellectual property apply to all members of the organizations, whether rich or poor." That is why one could argue that their criticism is weakened as it adopts the language of the discipline and, to some extent, it adopts its logic. Although many activists within the movement are convinced that the intellectual property system is an unfair system benefitting only a small number of countries that are "IP exporters," the approach they choose toward IP rules tends to naturalize those rules. Thus, in a way, their efforts contribute to maintaining the vision of a reality they repudiate (the supremacy of IP rules over other types of rules). This is certainly one of the limits of the struggle from the within.

\section{Acquiring the Knowledge to Redefine the Public Space}

During the negotiation of the free trade agreement with the United States, NGOs and academics produced materials to spread knowledge about intellectual protections and share their interpretation of the texts: a book in Thai and English (Bamford et al. 2005), articles and publications, videos, leaflets, t-shirts, etc. Activists knew that they needed to translate "the technical nature" of the agreements and explain to a larger audience what the legal text and its criticisms meant (Interview with Ungpakorn, January 24, 2006). Specific concerns of individuals or groups within the network of activists were integrated into the arguments developed by experts in order to broaden the mobilization. Several organizations in Thailand collaborated to support the action of the TNP+, including the Drug Study Group, MSF, Access Foundation, FTA Watch (a network gathering a dozen of different civil society mobilizations against the FTA, from farmers and trade unionists to patients and even bankers). They developed a specific curriculum to educate activists in intellectual property law. Trainings over several days took place in the different sections of TNP+ across the country. These initiatives helped people understand the impact of the matter for themselves (Interview with Limpananont, August 27, 2007). A small army composed of eighteen persons was deployed to travel across the network and explain these issues in different regions (Interview with Brigitte Tenni, volunteer with the TNP+, August 28, 2007). Trainers were informed of national or international developments by other members within the organization or allies in the network of experts. Regional meetings were organized

${ }^{12}$ However, activists involved on WTO issues did campaign for "least developed countries" (LDCs) to be allowed not to apply patents on pharmaceuticals before a certain date (2016, later postponed to 2033). But this is rather marginal as it only concerns a handful of countries and does not constitute a sustainable exemption to general principles and rules established by TRIPS. 
every couple of months to share the information, for instance about ongoing negotiations over intellectual property and access to medicines at the WTO or at the WHO.

Most people believed that FTA agreements are mere economic agreements and concern tariffs only (Interview with Buntoon Setsiroj, member of FTA Watch, January, 23, 2009). As a consequence, these agreements are generally not considered as directly affecting social matters such as healthcare. A phase of translation, education, and dissemination of knowledge was thus conducted by activists, something like an effort to achieve the "translatability between the world of everyday material experience and the world of science" (Rancière 2003). The impact of intellectual property has to be considered in relation to the everyday existence of those individuals whom activists want to mobilize and whose support they wish to rally. It must be related to the register of the material lives and bodies of individuals who are patients or could become patients. In 2006, activists produced a sticker with a drawing showing somebody with a dollar sign on the tie dropping pills into the mouth of a patient and stating "Right to $C L=$ Right to live" (see image below).

CL is Compulsory Licensing, a legal provision authorized by the WTO thanks to which governments can lift patent protection to obtain generics when they consider it necessary. Several of the provisions requested by the US in the FTA negotiation directly threatened the use of this provision. This sticker, which activists distributed during events and demonstrations, exemplifies the appropriation of languages-legal language and English-- and of a legal culture by these activists during the FTA negotiations. When they marched in the streets, they demanded "No TRIPs plus in FTA" and claimed "Don't trade away patients' lives for TRIPS plus." They also demanded that "IPR [be] out of FTA." In clear language, the protestors strongly rejected the standards of protection of intellectual property in the free trade agreement that went beyond what the TRIPS agreement of the World Trade Organization already requires. They even demanded that the chapter on intellectual property rights be excluded from the trade agreement. Thus, beside more traditional slogans such as "Thailand is not for sale," "shameless negotiator" or "treat the people," that anybody could presently understand, they delivered messages that only an elite could make out. The fact that thousands of people marched behind such banners illustrates the acquisition and re-appropriation by the crowd of a legal knowledge and legal language. It also demonstrates the desire of treatment activists to make use of the knowledge and codes of the experts in order to convey their own political message to the negotiators and the governments. They wanted to prove both their command of the matters at stake in the negotiation and the terms of the debate, and that they intended to contribute to it. To try to counter the dominant influence of the pharmaceutical lobbyists and of the US administration on policy-making, activists of the accessto-medicines movement appropriated their opponents' actual tools of power--the knowledge and language that had served to exclude citizens from the space of the negotiation, for instance. Knowledge is a resource for grounding political claims, as it was with AIDS groups in the 1990s, but it is also "the very target of activism" (Rabeharisoa et al. 2013). A system was set up by the Thai activists to acquire and share knowledge within their movement. That knowledge was then displayed in public spaces where it appeared as what it is to them: a means to redefine the 
political space and the political ground on which citizens can set foot. They did not go as far as entering the negotiation room, but they colonized the fringes of the

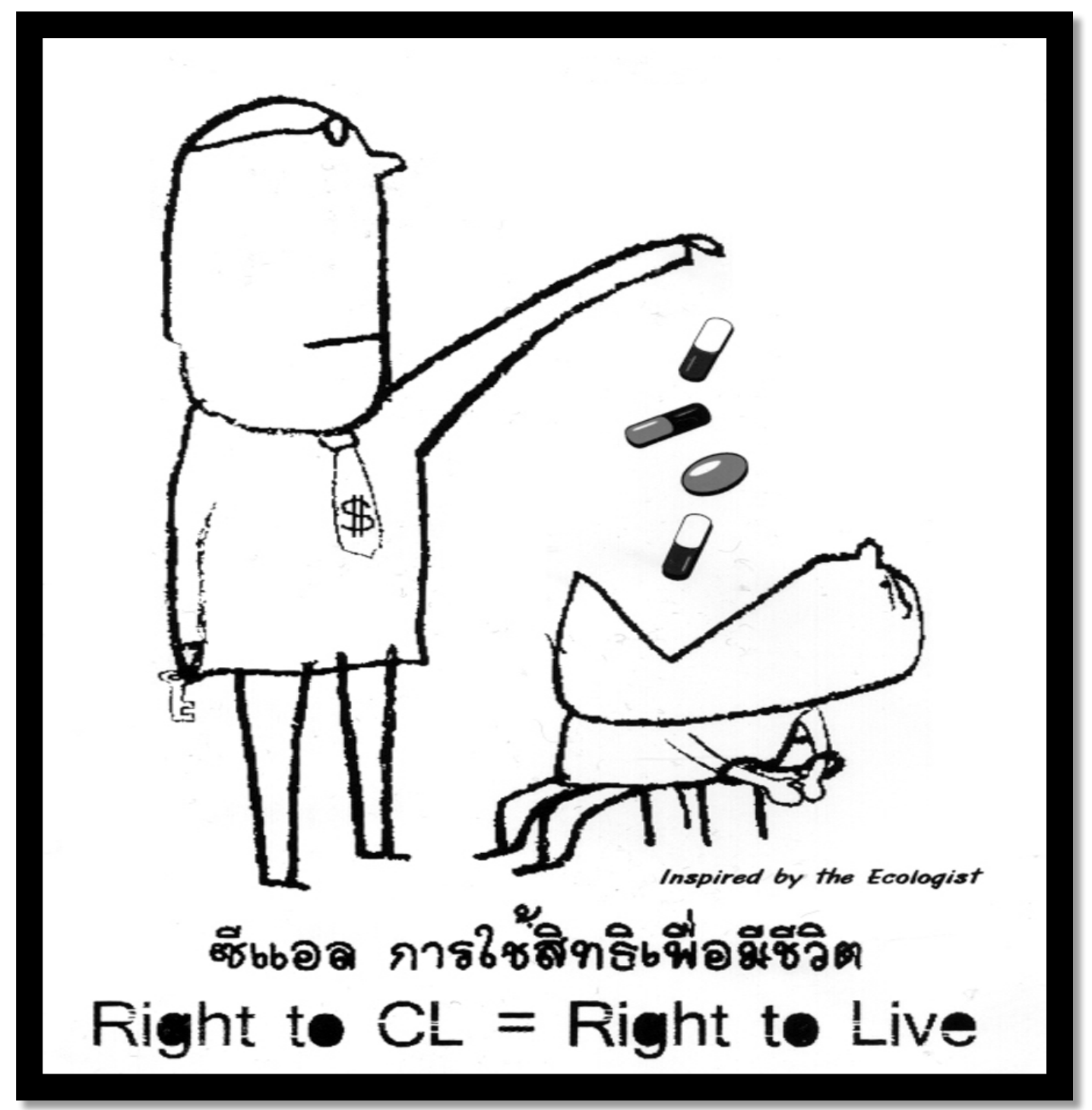

Figure 1. Activist Sticker "Right to $C L=$ Right to live"

negotiation, and various national institutional arenas. Several times did the Thai government decide to organize meetings with civil society to present and discuss some aspects of the negotiation, including the IP chapter. Many times did representatives of the government and negotiators react on this issue in the media and try to reassure citizens. Even the head of the US 
negotiating team felt she had to meet with the representatives of the access-to-medicines movement after the Chiang Mai demonstration.

Activists defending access to medicines in Thailand, similarly to evidence-based activism, operate "from within" the realm of the knowledge they target. They occupy knowledge as if it were a territory and question the hegemonic messages and interpretations spread by lawyers and the representatives of government regarding what the law says and what the subjects of the law can do; in so doing, they challenge the elites and engage in cultural politics (Conway 2006). Although they have a more reverent relation to the dominant knowledge than EBA, as therapeutic activism did with medical science, thanks to their mobilization of knowledge, they contribute to reshaping the political space around the issue of IP and medicines: opening up, to some extent, the negotiating spheres of the FTA to health concerns and activists' views over patent rules, forcing negotiators to organize public meetings or meetings with activists, pushing the issue in the public debate through media.

\section{A Hybrid Form of Collective Action}

Despite their orthodox relation to dominant knowledge, activists' efforts to appropriate language and techniques of law and the invasion of the legal field by lay persons support a form of political criticism of the economy of pharmaceuticals. They also support social emancipation. It is based on the development of specific modes of relations and collaborations between the different actors serving the movement, such as grassroots activists and experts. As Evidence-Based Activism in the medical realm, which rests on "a collective inquiry associating patients/activists and specialists / professionals in the conjoint fabrics of scientific statements and political claims" (Rabeharisoa et al. 2013), there is no strict dichotomy between lay persons and specialists of IP within the movement for access to medicines. This type of alliance-of IP lawyers and experts doing activism and HIV patients trained to explain question of IP law, for instance--defines what the movement for access to medicines is, and the kind of activism it develops within the frontiers of the movement, at its fringes, and beyond.

Beside the relationships they already have had with civil servants and policy makers in the healthcare field, conflicts over patents have allowed treatment activists to regularly get in touch with national institutions in charge of IP, industrial policy, and trade since the end of the 1990s. Indeed, there were several such episodes: the opposition to the ddI patent (1998-2001); the challenge of the BMS patent in court (2001); mobilizations against the several phases when the US government has exerted pressure to increase patent protection since the 1990s; several campaigns for compulsory licensing (from 1998 to 2008), and the opposition to the patent on Combivir® in 2006 (see Wibulpolprasert 2011; Kuanpoth 2010; Krikorian 2009). In the context of the negotiation of the FTA with the US, some civil servants of the Ministry of Foreign Affairs (in charge of conducting the talks) or of the Ministry of Trade, were at first suspicious or even averse to criticisms of the FTA, yet they later developed a better understanding of these criticisms along the process, thanks to repeated contacts. As an activist once mentioned, the most difficult task was often to obtain a first meeting (Interview with Nimit Tienudom, director of the AIDS Access 
Foundation, February 1, 2006). Once the discussion had started, the level of expertise of the activists helped them keep the exchange going. As Kamon Upkaew recalled:

\begin{abstract}
Initially, through the ddI case, we became familiar with some of the people through the academic network, but really it's the FTA which led us to know more key people in ministry of commerce. (...) There was a lot of information sharing. And we see that... It's not so confrontational... We see that there are civil servants within that ministry that are willing to discuss too. We all acknowledge that it is a real political issue. So, the more we can work with the ministry, then the ministry speaks at the policy level. That's beneficial because most of the people we work with don't hold any power, so it's about working together in order to get to the level of politics. (...) Even if we are trying to reach the top level politicians, such as the prime minister, we rarely manage to reach them; so what we do is find allies at the parliamentary level who are interested in our issues, that can educate their peers, and our work is done through them because we don't have a space to talk directly to a lot of the top official people. (Interview with Kamon Upkaew from TNP+, January 26, 2006)
\end{abstract}

The sharing of a common language between lay-experts and women and men who represented the government in the negotiation of an FTA was also an opportunity for the latter to benefit from the expertise and arguments developed by the social movements. Typically, such input can be particularly useful in the context of the unbalanced relationship between trade partners where countries such as Thailand has fewer resources (human, economic, in terms of expertise, etc.) than their US counterpart. While they face strong pressures from the private sector and/or foreign States on policy making, civil servants may as well benefit from the existence of social mobilizations in the street or in the media to serve them in the power balance.

Moreover, similarly to industry and its ties inside governments, knowledge activist relationships frequently rest in part on elements of individuals' personal history (being alumni of the same school or having common friends or colleagues, for instance). One activist studied in the same school as one of the negotiators of the Ministry of Foreign Affairs. Another studied pharmacy along with a civil servant of the Ministry of Healthcare. A third studied with the wife of a Minister who, as an academic, could access certain meetings of the negotiation which only negotiators were usually allowed to attend. The director of one of the key public health institutions involved in the debate was himself affected by a deadly disease. A doctor involved in the movement was in medical school with another one who later became an advisor to the Minister of Public Health. Many of the highly educated middle class members of the movement for access to medicines have connections that facilitate a stable back-and-forth communication with governmental institutions. The knowledge activism at play in Thailand rests on a collaboration between actors of the movement for access to medicines, i.e. people who identify themselves as activists, among whom there are expert activists-be they doctors, lawyers, pharmacists, academics, journalists--and actors who are not members of the movement but make themselves useful to it, generally because they agree with some of its objectives (to expand the access to medicines, to produce generics locally, to use compulsory licensing, to refuse TRIPS 
provisions in the FTA, etc.). Their contribution can take many forms: leaking written material, sharing key information, exchanging information when they officially meet activists, or simply taking into account and making use of the arguments advanced to them.

This form of activism is based on the relations and circulation of information between these different types of actors. The existence of this continuum of knowledge and information, transferred through the social movement for access to medicines from grassroots activists to civil servants and policy makers, played a prominent role in the issuing by the Thai Minister of Public Health of compulsory licenses in 2007 and 2008, when so many countries with the same needs chose not to do so (Krikorian 2009; 2014). It is similar to "boundary movements," through which boundaries between active members of the movement and actors who are not part of the movement are blurred (McCormick, Brown and Zavestoski, 2003). A hybrid form of collective action has developed that goes beyond the movement and reconfigures itself constantly, depending on opportunities or pressures. The exchanges and relations between actors is part of a history broader than the battle against the FTA and cannot be limited to a purpose-specific coalition. They result from, and are nurtured by, preexisting relationships of collaboration and mutual identification; they are also open to new opportunities that can arise along fronts of tension within policy making. The genealogy that one can draw between AIDS activism and the movement for access-to-medicines allows us to trace the origin of the latter. One can follow it considering the trajectory of a person who has joined mobilizations to end discrimination against HIV-positive people, an initial effort that has turned into campaigning for access to drugs, which led her or him to denounce the negative impact of intellectual-property protections barring access to such medicines. Highlighting the genealogy, thus, helps understand key features at the core of this movement, but the analysis also shows that, from the outset, it developed in a new form of activism that I choose to call "knowledge activism."

\section{Conclusion}

A global movement has formed to bridge the gap between people living with HIV / AIDS in rich countries and people in the Global South. It has put generic medicines at the core of its demands. Intellectual property has become a central field of contention, first regarding WTO rules, then concerning free trade agreement provisions and their rules on intellectual property. A new and situated notion of access to medicines was forged: emerging in the context of the global AIDS epidemic, in reaction to the inequality of access for patients across the world, and in tension with the intellectual property rules governing the pharmaceutical market. In this story, the nature of the knowledge necessary for activists to support their demands is a new feature. The production of this new framing of the issue of "access" also corresponds to the investment of a new form of knowledge. But there is more to it: there emerges a specific form of activism, which I call knowledge activism, has four main characteristics.

First, the access-to-medicines movement in Thailand develops a feature highlighted by the scholars who have described the Evidence Base Activism (EBA): the capacity to acquire and mobilize a variety of knowledge or fields of science. It illustrates the deployment of a form of 
activism that can be seen more as a relationship to knowledge in general than as the appropriation of a certain kind of knowledge: it moves between different fields of knowledge, even those that are very distant from activists' everyday life. To counter the dominant influence of the pharmaceutical lobbying and of the US administration on policy making, and in particular during the FTA negotiations, activists appropriate their opponents' actual tools of power to counter them. Knowledge is "the very target of activism" (Rabeharisoa et al. 2013), and a real system is set up by the Thai activists to acquire and share it within their movement.

Second, similarly to evidence-based activism, knowledge activists operate "from within" the realm of the knowledge. However, they do not question the authority of intellectual property law as such and have a rather reverent approach to the domain of knowledge. Although many activists feel strongly about the IP system that they consider unfair, their approach towards IP rules tends to naturalize them. They end up challenging the interpretation and use that the elites make of IP law, rather than questioning the structural prominence of these legal rules in public policies.

However, and third, as they dispute the hegemonic messages and interpretations spread by lawyers and the representatives of governments regarding what the law says and what the subjects of the law can do, they perform a political act. Because they both challenge the economy of pharmaceuticals and occupy knowledge as if it were a territory. During the trade negotiations, by means of demonstrations, flyers, books, slogans, they intend to prove that they master the matters at stake and the terms of the debate. They demonstrate that they intend to contribute to it; even if they are not invited, they intend to enforce, through the above-mentioned public actions, their participation in the negotiating sphere from which they and healthcare concerns would be excluded otherwise. Thus, through their mobilization of and relation to knowledge, they contribute to reshape the political space around the issues of IP and medicines, and they challenge the conditions of the citizens' access to this space.

Finally, the movement for access to medicines shows no strict dichotomy between lay persons and specialists of IP while it engages with individuals standing at its fringes, or even beyond its frontiers. Academics and lawyers are fully part of the movement. Collaborating with them and other activists makes it possible to appropriate and use knowledge. It is a collaboration that characterizes the form of activism in action and is based on the relations and circulation of information between these different types of actors. The activism at play is fueled by exchanges and relations among actors that were part of a history broader than the fight against the FTA and that cannot be limited to a purpose-specific coalition. It results from, and is nurtured by, preexisting relationships of collaboration and mutual identification but is open to new opportunities that can arise along fronts of tensions that surround policy making on IP and medicines. As a result, boundaries between active members of the movement and actors outside of the movement tend to blur. Knowledge activism presents a hybrid form of collective action that allows circulation of knowledge and communication between various actors; it expands beyond the movement and reconfigures constantly, depending on opportunities or pressures. 


\section{Author Biography}

Gaëlle Krikorian is currently a post-doc at the National Institute for Health Research (Inserm) / IRIS, Institut de recherche interdisciplinaire sur les enjeux sociaux. Sciences sociales, politique, santé (CNRS-Inserm-EHESS-University Paris 13). Her researches in sociology concern social movements, globalization, health and technologies. Previously she analyzed the way health and access to medicines issues are taken into account during the negotiation of Free Trade Agreements. Her current work explores the use of DNA by the police and the justice and the emerging of new genetic technologies in this domain. She is also conducting a research on the notion of right to medicines and its relations to the economics of pharmaceuticals in the global South as well as in Western countries. Dr. Krikorian holds a PhD in Sociology from the Higher School of Social Studies, EHESS, Paris, France.

\section{Acknowledgements}

I would like to gratefully acknowledge Vololona Rabeharisoa for her critical reading of the manuscript and her invaluable comments, and Maurice Cassier for his advice and for the fruitful conversations. I would like to thank Karyn Kaplan for acting as interpreter during the interviews that took place in Thai language, and Sébastien Le Pipec for his support in revising the English language of this paper. Finally, I would like to thank the reviewers for their thoughtful comments that helped me strengthen the key arguments I am presenting, as well as ESTS editors Katie Vann and Daniel Kleinman for their guidance during the production of this contribution. The fieldwork on which it is based was funded by the French National Agency for Research on AIDS and Hepatistic (ANRS).

\section{References}

ACT UP New York (1996). Remarks at the Opening Ceremony by Eric Sawyer. XIth International $\begin{array}{lllll}\text { AIDS Conference, } & \text { Vancouver }\end{array}$ http:/ / www.actupny.org/Vancouver/ sawyerspeech.html

Bamford, Chanida Chanyapate and Alec Bamford (eds.) (2005). Free Trade Agreements and Their Impact on Developing Countries: The Thai Experience, Bangkok: FTA Watch.

Barbot Janine (1998). "Science, marché et compassion. L'intervention des associations de lutte contre le sida dans la circulation des nouvelles molecules," Sciences Sociales et Santé, 16 (3), p. 76-95.

Barbot, Jeanine (2002). Les malades en mouvements: la medecine et la science a l'épreuve du sida. Paris: Balland.

Blume, Stuart (1999). Histories of cochlear implantation. Social Science and Medicine 49(9): 12571268.

Blume, Stuart (2000). "Land of Hope and Glory: Exploring Cochlear Implantation in the Netherlands," Science, Technology, and Human Values, 25(2) 2: 139-166. 
Bourdieu, Pierre (1983). "Forms of capital." In J. C. Richards (ed.). Handbook of Theory and Research for the Sociology of Education. New York: Greenwood Press.

Broqua, Christophe et Olivier Fillieule (1996). "Engagement et revendication communautaires face au sida," Transcriptases, Revue critique de l'actualité scientifique internationale sur le VIH et les virus des hépatites, n44 - avril 96.

Biehl, Joao (2010). "Human Pharmakon: Symptoms, Technologies, Subjectivities." In A Reader in Medical Anthropology: Theoretical Trajectories, Emergent Realities edited by Byron Good, Michael M.J. Fischer, Sarah Willen, Mary-Jo DelVecchio Good, pp.213-231. Malden, MA: Wiley-Blackwell.

Brown, Phil, Zavestoski, Stephen, McCormick, Sabrina, Mayer, Brian, Morello-Frosch, Rachel and Rebecca Gesior Altman (2004). "Embodied Health Movements: New Approaches to Social Movements in Health." Sociology of Health and Illness, 26(1): 50-80.

Conway, B. (2006) Foreigners, faith and fatherland: The historical origins, development and present status of Irish sociology. Sociological Origins 5(1): 1-36.

Dalgalarrondo, Sébastien (2004). Sida, la course aux molécules. Paris, Éditions de l'EHESS.

Dalgalarrondo, Sébastien and Philippe Urfalino (2000). "Choix tragique, controverse et décision publique. Le cas du tirage au sort des malades du sida." Revue française de sociologie, Volume 41 Numéro 1 pp. 119-157.

Dodier, Nicolas (2003). Leçons politiques de l'épidémie de sida. Paris: Éd. de l'École des hautes études en sciences sociales.

Dodier Nicolas et Jeanine Barbot (2000). "Le temps des tensions épistémiques. Le développement des essais thérapeutiques dans le cadre du sida (1982-1996)." Revue française de sociologie, XLI (1), 79-118.

Edwards Claire, Howlett, Etaoine, Akrich, Madeleine and Vololona Rabeharisoa (2014). "Attention deficit hyperactivity disorder in France and Ireland: Parents' groups' scientific and political framing of an unsettled condition," BioSocieties 9(2): 1-20.

Epstein, Steven (1995). "The construction of lay expertise: AIDS activism and the forging of credibility in the reform of clinical trials." Science, Technology, and Human Values, 20(4), 408-437.

Epstein, Steven (1996). Impure Science: AIDS, Activism, and the Politics of Knowledge. Berkeley, CA: University of California Press.

Frickel, Scott, Torcasso, Rebekah and Annika Anderson (2014). "The Organization of Expert Activism: Shadow Mobilization in Two Social Movements." The Independence of Experts in Question: Toward a Political Sociology of Health Expertise. Maison Interuniversitaire des Sciences de l'Homme-Alsace, Strasbourg: France (May 14-16, 2014), under review.

Heywood, Marc (2009). "South Africa's Treatment Action Campaign: Combining Law and Social Mobilization to Realize the Right to Health." Journal of Human Rights Practice 1(1):14-36. doi.org/10.1093/jhuman/hun006

Kapczynski, Amy and Jonathan M. Berger (2009). "The Story of the TAC Case: The Potential and Limits of Socio-Economic Rights Litigation in South Africa." In Human Rights Advocacy 
Stories, edited by D. R. Hurwitz and M. L Satterthwaite. New York: Thomson Reuters/Foundation Press, 43-80.

Kapstein, Ethan et Joshua Busby (2013). AIDS Drugs for All. Social Movements and Market Transformations. Cambridge University Press.

Krikorian G. and Szymkowiak D. (2007). "Intellectual property rights in the making: the evolution of intellectual property. Provisions in US free trade agreements and access to medicine." The Journal of World Intellectual Property, 10 (5): 388-418.

Krikorian G. (2009). "The politics of patents: conditions of implementation of public health policy in Thailand." In S. Haunss and K. C. Shadlen (eds.), The Politics of Intellectual Property: Contestation over the Ownership, Use, and Control of Knowledge and Information, 29-55. UK: Edward Elgar Publishing.

Krikorian, Gaëlle (2014). “La propriété ou la vie? Économies morales, actions collectives et politiques du médicament dans la négociation d'accords de libre-échange." Maroc, Thailande, États-Unis. Thèse, EHESS, Soutenue le 10 Janvier 2014. Kuanpoth, Jakkrit (2010). Patent Rights in Pharmaceuticals in Developing Countries, Major Challenges for the Future. Edward Elgar Publishing.

Limpananont, Jiraporn (2005). "Impact of U.S.-Thailand FTA on access to medicines in Thailand." In C. Chanyapate Bamford and A. Bamford (Eds.), Free Trade Agreement: Impact in Thailand, Bangkok, Thailand: FTA Watch, 59-74.

Love, James (2011). “De-linking RandD costs from product prices," Knowledge Ecology International 1 April 6, 2011.

McCormick, Sabrina (2007). "Democratizing Science Movements: A New Framework for Mobilization and Contestation." Social Studies of Science, 37(4): 609-623.

McCormick, Sabrina, Brown, Phil, and Zavestoski, Stephen (2003). "The personal is scientific, the scientific is political: The public paradigm of the environmental breast cancer movement." Sociological Forum, 18: 545-576.

Moreira, Tiago, O'Donovan, Orla, and Howlett, Etaoine. (2014). "Assembling Dementia Care: Patient Organisations and Social Research," BioSocieties 9, 173.

Nguyen, Vinh-Kim (2005). "Antiretroviral Globalism, Biopolitics, and Therapeutic Citizenship." In Global assemblages: technology, politics, and ethics as anthropological problems, edited by Ong, Aihwa and Stephen J. Collier. Malden, 124-144. MA: Blackwell Press.

Nguyen, Vinh-Kim (2010). The Republic of Therapy: Triage and Sovereignty in West Africa's Time of AIDS. Durham, N.C.: Duke University Press.

Parker, Richard (2011). “Grassroots Activism, Civil Society Mobilization, and the Politics of the Global HIV / AIDS Epidemic." The Brown Journal of World Affairs, 17(2), Spring 2011.

Petryna, Adriana, Andrew Lakoff and Arthur Kleinman (eds.) (2006). Global Pharmaceuticals: Ethics, Markets, Practices. Durham, NC: Duke University Press.

Pérez-Casas, Carmen (2000). HIV/AIDS medicines pricing report. Setting objectives: is there a political will? Rapport publié le 6 juillet 2000 par Médecins Sans Frontières. 
Rabeharisoa, Vololona (2006). "From representation to mediation: The shaping of collective mobilization on muscular dystrophy in France." Social Science and Medicine, 62(3): 564576.

Rabeharisoa, Vololona, Moreira, Tiago and Madeleine Akrich (2013). "Evidence-based activism: Patients' organisations, users' and activist's groups in knowledge society." Unpublished Work, CSI WORKING PAPERS SERIES 033.

Rabeharisoa, V., Moreira, T. and Akrich M. (2014). “Evidence-based activism: Patients', users' and activists' groups in knowledge society." BioSocieties 9(2): 1-18.

Rancière, Jacques (2003). Les Scènes du peuple (Les Révoltes logiques, 1975-1985). Lyon: Horlieu.

Robins, Steven (2004). "'Long live Zackie, long live': AIDS activism, science and citizenship after apartheid." Journal of Southern African Studies, Vol 30, No. 3, 651-672.

TAC (2007a). Electronic Newsletter. Published 7 February, 2007. Available at: http:/ / www.tac.org.za/community/node/ 2173

TAC (2007b), Annual report, March 2006 to February 2007.

Tilly, C. (2005). Identities, boundaries, and social ties. Boulder, CO: Paradigm Publishers.

Wibulpolprasert, Suwit, Chokevivat, Vichai, Oh, Cecilia et Inthira Yamabhai (2011). "Government use licenses in Thailand: The power of evidence, civil movement and political leadership." Global Health. 2011; 7: 32.

Wilson, D., Keiluhu A.K., Kogrum S., Reid T., Seriratana N., Ford N., Kyawkyaw M., Talangsri P., Taochalee N. (2009). "HIV-1 viral load monitoring: an opportunity to reinforce treatment adherence in a resource-limited setting in Thailand," Transactions of the Royal Society of Tropical Medicine and Hygiene, 103(6): 601-6. doi: 10.1016/j.trstmh.2008.11.007. 